\title{
Proximate chemical composition and lipid profile of Indian mackerel fish
}

\author{
Amal Nassir ALKURAIEEF ${ }^{1}$, Amnah Mohammed ALSUHAIBANI ${ }^{1 \star ~(D), ~ A m a l ~ H a s s a n ~ A L S H A W I ~}{ }^{1}$, \\ Amani Hamzah ALJAHANI ${ }^{1}$, Moneera Othman ALJOBAIR ${ }^{1}$, Najla Abdullah ALBARIDI ${ }^{1}$
}

\begin{abstract}
Fish and fish products of the most available protein sources for human beings. Indian mackerel is the most available and economic fish sold in markets in different countries and is included in many local dishes. Indian mackerel are characterized by dark muscles because of the high contents of myoglobin and lipids. This study aims to investigate the chemical composition, saturated and unsaturated fatty acid contents, and fatty acid fractions in Indian mackerel muscle. Indian mackerel ( $R$. kanagurta) were purchased from the central fish market in Jizan, which is caught from the port of Jizan, Saudi Arabia. The samples were analyzed to estimate the proximate chemical composition, Lipid Fractions, and Fatty acid analyses from Indian mackerel. In this study, revealed that moisture, protein, and fat are the main constituents of Indian mackerel. The Indian mackerel contained high and comparable levels of saturated fatty acids and unsaturated fatty acids, and the different samples exhibited somewhat similar fatty acid contents. Among unsaturated fatty acids, the content of polyunsaturated fatty acids was higher than that of monounsaturated fatty acids, and those with the highest levels in Indian mackerel were palmitoleic, palmitic, myristic, oleic, 15-tetracosenoic, linolenic, and stearic acids in addition to docosanoic, eicosanoic, 5,8,11,14,17-eicosapentanoic, and 11-eicosenoic pentadecanoic acids. We conclude Indian mackerel is a rich source of protein and lipids. Polyunsaturated fatty acids are the main constituents of lipids, which exert positive effects on the body by providing the main nutrients and preventing disease in the consumer.
\end{abstract}

Keywords: Indian mackerel; chemical composition; lipids; fatty acids.

Practical Application: Providing information about the chemical composition, saturated and unsaturated fatty acid contents, and fatty acid fractions in Indian mackerel fish.

\section{Introduction}

Some of the most available protein sources for human beings of fish and fish products, which represent approximately $80 \%$ of animal protein. There is strong evidence that fish are rich sources of vitamins such as B12 and B6 and minerals, especially iodine and fluorine, which are required for the prevention of goiter and promote strong teeth and bones (Håstein et al., 2006).

Indian mackerel (Rastrelliger kanagurta) belongs to the family Scombridae and is commonly found in the coastal areas of the Indian Ocean. Mackerel fish are also found in the waters of the Red Sea and the Arabian Gulf and are abundant in summer. Mackerel arrives in India and forms the basis of pelagic fisheries after sardines, representing 7.2\% of total marine fish (Sofi et al., 2016). Indian mackerel is the most available and economic fish sold in markets in different countries and is included in many local dishes. Indian mackerel is characterized by a blue-green color on the back, silver flanks and a golden tint. The size of Indian mackerel varies in length, reaching $21.7 \mathrm{~cm}$ at 8.6 months old. Additionally, Indian mackerel are characterized by dark muscles because of the high contents of myoglobin and lipids. Mackerel is a fatty fish and a good source of marine lipids; thus, increasing the consumption of this fish is good for human health
(Abdussamad et al., 2010; Chaijan et al., 2004). The high levels of amino acids, fatty acids, minerals and vitamins in Indian mackerel play a positive role in human nutrition (Viji et al., 2015; Corapci \& Guneri, 2020).

The objective of this study was to investigate the chemical composition, saturated and unsaturated fatty acid contents, and fatty acid fractions in Indian mackerel muscle and to compare the obtained results with previously available data.

\section{Materials and methods}

\subsection{Collection and preparation of Indian mackerel samples}

Indian mackerel (R. kanagurta), $17 \pm 3 \mathrm{~cm}$ in length, were purchased from the central fish market in Jizan, which is caught from the port of Jizan, Saudi Arabia. Fish samples were transported to the laboratory in an ice box as soon as possible and were analyzed within 24 hours of catching them.

Fish were prepared by cutting the samples using sterile cutters and homogenizing obtain three samples of Indian mackerel muscle for chemical analysis, Lipid Fractions and Fatty Acids analyses. 


\subsection{Chemical analysis}

Moisture, ash, protein, and fat were estimated in Indian mackerel by the methods described by the Association of Official Analytical Chemists (2012). All analyzes were performed in three iterations. The carbohydrate content was calculated as follows (Mathew et al., 2014; Equation 1):

Total carbohydrates $=100-($ moisture + ash + protein + total lipids $) \%$

\subsection{Determination of lipid fractions and fatty acids analysis}

Fatty acids were obtained from total lipids by acid-catalyzed transesterification according to (Christie \& Han, 2012). amount of $100 \mathrm{mg}$ of the extracted lipid was dissolved in $1.5 \mathrm{~mL}$ dichloromethane and $3 \mathrm{~mL}$ methanol-sulfuric solution (200:3 at a volume ratio) and shaken vigorously. The reaction mixture was heated at $100^{\circ} \mathrm{C}$ for approximately $1 \mathrm{~h}$ and then cooled to room temperature. Subsequently, $3 \mathrm{~mL}$ hexyl hydride and $1 \mathrm{~mL}$ distilled water were added to the mixture. After vortexing and layering, the entire upper phase was collected. One gram of anhydrous sodium sulfate was added to the collected sample and then stewed for overnight stratification. After filtration, the sample was evaporated until its weight turned to be constant under a stream of nitrogen. Heptane was added to the sample to make up a final concentration of $50 \mathrm{mg} \mathrm{mL}^{-1}$. The qualitative analysis of Fatty acids was by column chromatography (CC MSQP5050A System: model 2001, Shimadzu, Japan; autosampler, Shimadzu, Japan; serial number, C111437075). The quantity of each fatty acid was determined by calculating the peak area relative to the total area of the peak. These values are indicated by fatty acid content (\%).

\subsection{Statistical analysis}

Data are presented as the mean \pm standard deviation $(n=3)$ and were analyzed by one-way analysis of variance (ANOVA) using Minitab 17 software. The significance level was $\mathrm{p}<0.05$.

\section{Results}

\subsection{Proximate chemical composition}

The average chemical composition of the tested Indian mackerel samples purchased from different markets in March was investigated and is shown in Table 1. The average moisture, protein, fat, ash and carbohydrate contents were $74.33 \pm 0.39$, $20.89 \pm 0.07,3.23 \pm 0.26,1.26 \pm 0.14$, and $0.29 \pm 0.14 \mathrm{~g} / 100 \mathrm{~g}$, respectively.

\subsection{Composition of lipids}

The obtained results in Table 2 and Figure 1 show that the tested Indian mackerel contained high levels of saturated fatty acids, reaching $27.01 \pm 0.07 \mathrm{mg} / 100 \mathrm{~g}$, followed by a similar content of unsaturated fatty acids, which were present at a level of $26.02 \pm 0.07 \mathrm{mg} / 100 \mathrm{~g}$. Unsaturated fatty acids are composed of polyunsaturated fatty acids and monounsaturated fatty acids; the level of polyunsaturated fatty acids was higher $(22.01 \pm 0.06 \mathrm{mg} / 100 \mathrm{~g})$ than that of monounsaturated fatty
Table 1. Moisture, protein, fat, ash and carbohydrate contents in the muscle of Indian mackerel.

\begin{tabular}{lcccc}
\hline $\begin{array}{l}\text { Moisture } \\
(\mathrm{g} / 100 \mathrm{~g})\end{array}$ & $\begin{array}{c}\text { Protein } \\
(\mathrm{g} / 100 \mathrm{~g})\end{array}$ & $\begin{array}{c}\text { Fat } \\
(\mathrm{g} / 100 \mathrm{~g})\end{array}$ & $\begin{array}{c}\text { Ash } \\
(\mathrm{g} / 100 \mathrm{~g})\end{array}$ & $\begin{array}{c}\text { Carbohydrates } \\
(\mathrm{g} / 100 \mathrm{~g})\end{array}$ \\
\hline $74.33 \pm 0.39$ & $20.89 \pm 0.07$ & $3.23 \pm 0.26$ & $1.26 \pm 0.14$ & $0.29 \pm 0.14$ \\
\hline $\begin{array}{l}\text { Values of three independent replicates are expressed as the mean } \pm \text { SD [Standard } \\
\text { deviation]. }\end{array}$
\end{tabular}

Table 2. Saturated, unsaturated and trans fatty acid contents of Indian mackerel.

\begin{tabular}{ccccc}
\hline $\begin{array}{c}\text { Saturated } \\
\text { fatty acids }\end{array}$ & Unsaturated Polyunsaturated & Monounsaturated & Trans \\
$(\mathrm{mg} / 100 \mathrm{~g})$ & $(\mathrm{mg} / 100 \mathrm{~g})$ & $\begin{array}{c}\text { fatty acids } \\
(\mathrm{mg} / 100 \mathrm{~g})\end{array}$ & $\begin{array}{c}\text { fatty acids } \\
(\mathrm{mg} / 100 \mathrm{~g})\end{array}$ & $\begin{array}{c}\text { fatty acids } \\
(\mathrm{mg} / 100 \mathrm{~g})\end{array}$ \\
\hline $27.01 \pm 0.07$ & $26.02 \pm 0.07$ & $22.01 \pm 0.06$ & $4.01 \pm 0.01$ & $1.001 \pm 0.01$ \\
Values of three independent replicates are expressed as the mean $\pm \mathrm{SD}$. &
\end{tabular}

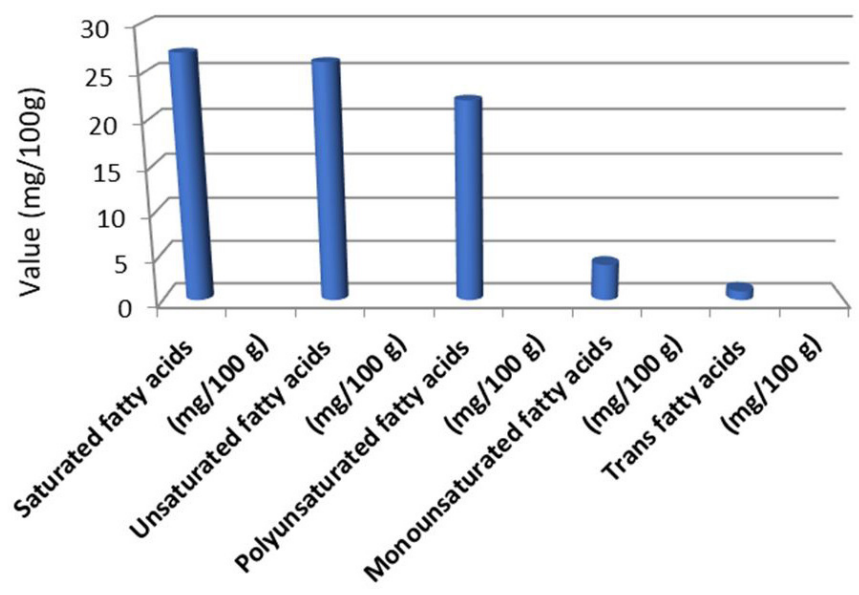

Types of fatty acids

Figure 1. Saturated, unsaturated and trans fatty acids content of Indian mackerel muscle.

acids $(4.01 \pm 0.01 \mathrm{mg} / 100 \mathrm{~g})$. The content of trans fatty acids was $1.001 \pm 0.01 \mathrm{mg} / 100 \mathrm{~g}$ in the tested Indian mackerel muscle.

\subsection{Lipid fractionation}

The data in Table 3 and Figure 2 indicate that the fatty acids with the highest contents in Indian mackerel were palmitoleic acid, palmitic acid, myristic acid, oleic acid, 15-tetracosenoic acid, linolenic acid, stearic acid CIS-13,16-docosadioic acid and cis-11,14,17-eicosatrienoic acid, with descending concentrations of $0.270 \pm 14.33,0.235 \pm 25.81,0.234 \pm 13.24,0.144 \pm 9.8730 .138$ $\pm 8.84,0.132 \pm 1.04,0.117 \pm 7.42,0.115 \pm 8.41$ and $0.10 \pm 3.47 \%$, respectively.

Additionally, Indian mackerel had relatively low levels of other fatty acids; the contents of the remaining fatty acids are listed in descending order: docosanoic acid, $0.081 \pm 0.46 \%$; eicosenoic (arachidic) acid, $0.066 \pm 0.92 \% ; 5,8,11,14,17$ eicosapentaenoic acid, $0.061 \pm 0.51 \%$; 11 -eicosenoic acid, $0.049 \pm 0.25 \%$; pentadecanoic acid, $0.047 \pm 1.25 \%$; heptadecanoic acid, $0.032 \pm 1.43 \% ; 8,11,14$-eicosapentanoic acid, $0.030 \pm 0.29 \%$; and Y-linolenic acid, $0.026 \pm 0.44 \%$. 
Table 3. Fatty acid composition of lipids in Indian mackerel muscle.

\begin{tabular}{lcr}
\hline \multicolumn{1}{c}{ Fatty acid \% } & Chemical formula & \multicolumn{1}{c}{ Mean $\pm \mathrm{SD}$} \\
\hline Myristic acid & $\mathrm{C}_{14} \mathrm{H}_{28} \mathrm{O}_{2}$ & $13.24 \pm 0.234$ \\
Pentadecanoic acid & $\mathrm{C}_{16} \mathrm{H}_{32} \mathrm{O}_{2}$ & $1.25 \pm 0.047$ \\
Palmitic acid & $\mathrm{C}_{16} \mathrm{H}_{32} \mathrm{O}_{2}$ & $25.81 \pm 0.235$ \\
Palmitoleic acid & $\mathrm{C}_{16} \mathrm{H}_{30} \mathrm{O}_{2}$ & $14.33 \pm 0.270$ \\
Heptadecanoic (margaric) acid & $\mathrm{C}_{17} \mathrm{H}_{34} \mathrm{O}_{2}$ & $1.43 \pm 0.032$ \\
Stearic acid & $\mathrm{C}_{18} \mathrm{H}_{36} \mathrm{O}_{2}$ & $7.42 \pm 0.117$ \\
Oleic acid & $\mathrm{C}_{18} \mathrm{H}_{34} \mathrm{O}_{2}$ & $9.873 \pm 0.144$ \\
Linoleic acid & $\mathrm{C}_{18} \mathrm{H}_{30} \mathrm{O}_{2}$ & $2.18 \pm 0.011$ \\
Eicosenoic (arachidic) acid & $\mathrm{C}_{20} \mathrm{H}_{40} \mathrm{O}_{2}$ & $0.92 \pm 0.066$ \\
Y-Linolenic acid & $\mathrm{C}_{18} \mathrm{H}_{30} \mathrm{O}_{2}$ & $0.44 \pm 0.026$ \\
11-Eicosenoic acid & $\mathrm{C}_{20} \mathrm{H}_{48} \mathrm{O}_{2}$ & $0.25 \pm 0.049$ \\
Linolenic acid & $\mathrm{C}_{18} \mathrm{H}_{30} \mathrm{O}_{2}$ & $1.04 \pm 0.132$ \\
Docosanoic (behenic) acid & $\mathrm{C}_{22} \mathrm{H}_{44} \mathrm{O}_{2}$ & $0.46 \pm 0.081$ \\
8,11,14-Eicosatrienoic acid & $\mathrm{C}_{20} \mathrm{H}_{34} \mathrm{O}_{2}$ & $0.29 \pm 0.030$ \\
Cis-11,14,17-Eicosatrienoic acid & $\mathrm{C}_{20} \mathrm{H}_{34} \mathrm{O}_{2}$ & $3.47 \pm 0.10$ \\
Cis-13,16-Docosadienic acid & $\mathrm{C}_{22} \mathrm{H}_{40} \mathrm{O}_{2}$ & $8.41 \pm 0.115$ \\
5,8,11,14,17-Eicosapentanoic acid & $\mathrm{C}_{20} \mathrm{H}_{30} \mathrm{O}_{2}$ & $0.51 \pm 0.061$ \\
15-Tetracosenoic acid & $\mathrm{C}_{24} \mathrm{H}_{46} \mathrm{O}_{2}$ & $8.84 \pm 0.138$ \\
\hline
\end{tabular}

Values of three independent replicates are expressed as the mean $\pm \mathrm{SD}$.

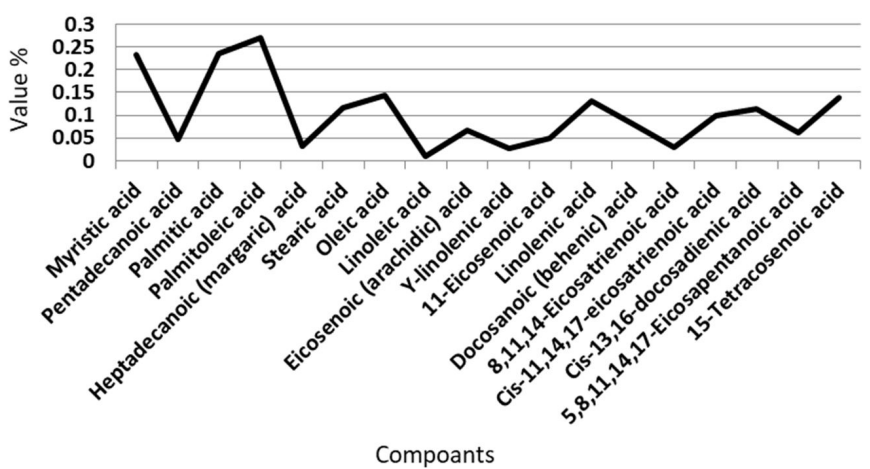

Figure 2. Fatty acid composition of Indian mackerel muscle lipids.

\section{Discussion}

The obtained proximate analysis results of Indian mackerel are excellent indicators of fish quality. Ahigh moisture content increases fish susceptibility to microbial spoilage and lowers its shelf life (Clucas, 1982; Oliveira et al., 2020). The moisture contents obtained in this study agreed with the results of Nurnadia et al. (2011) and Gokoglu \& Yerlikaya (2015), who observed 70-80\% moisture in fish muscle. Ali et al. (2013) also reported 72.8-76.6\% moisture in Indian mackerel from Oman.

It is known that fish protein is of good quality, containing a good amount of essential amino acids, and is highly digestible and a major source of energy (Pigott \& Tucker, 1990). The results of the protein analysis of Indian mackerel were like the results of Bandarra et al. (2001), who reported 18.3 to $19.9 \%$ protein in horse mackerel. In agreement with our findings, Nisa \& Asadullah (2012), Ali et al. (2013), Kumar et al. (2014) and Bahurmiz et al. (2017) estimated 15.1-22.4\% protein in Indian mackerel. Moreover, many researchers have reported that sex, species, age, environment, and season affect the chemical composition of fish (Bandarra et al., 2001; Celik, 2008; Sonavane, 2017; Oliveira et al., 2020b).

These outcomes agree with the conclusions of Tzikas et al. (2007) and Sone et al. (2019), who recorded that the moisture, protein, fat and ash contents of mackerel were $76.8 \pm 1.39 \%$, $20.3 \pm 0.68 \%, 1.3 \pm 1.08 \%$ and $1.5 \pm 0.08 \%$, respectively, throughout the year. The fat content of the muscle increased by $2.5 \%, 2.8 \%$ and $2.1 \%$ in March, April, and May, respectively, compared with that in February, with a decrease in moisture content to below $75.9 \%$. In contrast, in September and October, a low-fat content $(0.4 \%$ and $0.6 \%$, respectively) and high moisture content, reaching $78.2 \%$ and $77.6 \%$, respectively, were observed.

It has been reported that fish lipids are mainly composed of polyunsaturated fatty acids, especially docosahexaenoic and eicosapentaenoic acids, which can prevent and treat rheumatoid arthritis, coronary heart disease, diabetes, and cancers. Fatty acids play a positive role in osmoregulation, nutrient assimilation, and transport via the cell membrane (Ackman, 1982; Osman et al., 2001). The lipid content results from this study agreed with the results of Johnston et al. (1994), as the lipid content was low in lean, starved fatty fish $(0.5 \%)$ and increased to above $20 \%$ in well-fed, fatty fish. Additionally, Wickramanayake et al. (1989), Nisa \& Asadullah (2012), Kumar et al. (2014) and Bahurmiz et al. (2017) recorded that lipids accounted for $0.7 \%$ to $12.0 \%$ of the muscle content of mackerel caught in the Arabian Sea.

Our results showed that the ash content in mackerel muscles was $1.26 \pm 0.14 \%$, which was within the ranges of $0.5 \%$ and $1.8 \%$, as recorded by Sidwel (1981), and 0.9-1.4\%, as reported by Nisa \& Asadullah (2012) and Ali et al. (2013).

The obtained composition results of Indian mackerel showed predominantly saturated fatty acids followed by unsaturated fatty acids, both of which were present in a similar range. Unsaturated fatty acids are composed mainly of polyunsaturated fatty acids, which agrees with many studies, including those of Marichamy et al. (2009), Ganga et al. (2010) and Azim et al. (2018). Additionally, in a study on Atlantic mackerel, the fat content increased with an expected increase in food consumption and varied among years, seasons and geographic areas (catching grounds) in addition to individual variations in weight gain, as a higher total fat content is related to the feeding period and the size of the mackerel (Romotowska et al., 2016, 2017; Calixto et al., 2020).

The obtained fatty acid fractionation results of Indian mackerel contradict those of previous studies of different species, seasons, diets, and environmental conditions (Bahurmiz \& Ng, 2007; Hong et al., 2015; O’Neill et al., 2015; Wijekoon et al., 2014; Costa et al., 2020). It is well documented that docosahexaenoic acid and palmitic acid are the main fatty acids in aquatic fish (Sahena et al., 2009). Palmitic acid is needed for biosynthesis processes in fish and may play a role as a structural component of phospholipids in cell membranes (Pérez et al., 1999; Nascimento et al., 2020; Marques et al., 2020).

It has also been suggested that fish are rich in polyunsaturated fatty acids, such as eicosapentaenoic acid and docosahexaenoic acid, and have desirable components of a nutritious diet. Polyunsaturated fatty acids affect prostaglandin synthesis and hence encourage wound healing. $\omega-3$ and $\omega-6$ polyunsaturated fatty acids protect 
against cardiovascular diseases and cancer. Additionally, these fatty acids play a vital role in nervous, vision and reproductive system development and functions (Agusa et al., 2007; Luzia et al., 2003). Therefore, Indian mackerel is a rich source of protein and lipids. The Indian mackerel contained high and comparable levels of saturated fatty acids and unsaturated fatty acids, and the different samples exhibited somewhat similar fatty acid contents.

\section{Conclusion}

The present study revealed that Indian mackerel is a rich source of protein and lipids. Polyunsaturated fatty acids are the main constituents of lipids. The lipid profile of Indian mackerel showed high levels of palmitoleic acid, palmitic acid, myristic acid, oleic acid, 15-tetracosenoic acid, linolenic acid, and stearic acid, which exert positive effects on the body by providing the main nutrients and preventing disease in the consumer.

\subsection{Recommendations}

The obtained results showed favorable dietary components, mainly protein and lipids, in Indian mackerel and highlighted the importance of the lipid profile on the health of consumers and the application of different technological processes to avoid rancidity in fish. Further studies should be conducted on the amino acid, vitamin, and mineral contents of Indian mackerel in different seasons and catching areas.

\subsection{Significance statement}

This study estimates the proximate chemical composition, mainly those of protein and lipids of Indian mackerel and highlights the importance of the lipid profile to the health of consumers. This study will help researchers determine other nutrients, such as amino acids, vitamins, and minerals, in Indian mackerel and their differences between different seasons and catching areas, which many researchers have not been able to explore thus far. Thus, new theories on micronutrient combinations in Indian mackerel may be developed.

\section{Acknowledgements}

The authors are profoundly grateful to Princess Nourah Bint Abdulrahman University for its moral support in accomplishing this research paper. The authors are also grateful to the staff of the Ministry of Environment, Water and Agriculture, Riyadh, Kingdom of Saudi Arabia, for the financial assistance provided (T-A-5) to conduct this research.

\section{References}

Abdussamad, E., Pillai, N. G. K., Kasim, H., Habeeb, O., And, M., \& Jeyabalan, K. (2010). Fishery, biology and population characteristics of the Indian mackerel, Rastrelliger kanagurta (Cuvier) exploited along the Tuticorin coast. Indian Journal of Fisheries, 57, 17-21.

Ackman, R. G. (1982). Fatty acid composition of fish oils. In S. M. Barlow \& M. E. Stansby (Eds.), Nutritional evaluation of long-chain fatty acids in fish oil (pp. 25-88). London: Academic Press.

Agusa, T., Kunito, T., Sudaryanto, A., Monirith, I., Kan-Atireklap, S., Iwata, H., Ismail, A., Sanguansin, J., Muchtar, M., Tana, T. S., \&
Tanabe, S. (2007). Exposure assessment for trace elements from consumption of marine fish in Southeast Asia. Environmental Pollution, 145(3), 766-777. http://dx.doi.org/10.1016/j.envpol.2006.04.034. PMid:16828209.

Ali, A., Al-Abri, E. S., Goddard, J., \& Ahmed, S. (2013). Seasonal variability in the chemical composition of ten commonly consumed fish species from Oman. Journal of Animal and Plant Sciences, 23(3), 805-812.

Association of Official Analytical Chemists - AOAC. (2012). Official methods of analysis of AOAC International. Gaithersburg: AOAC International.

Azim, M. R., Hossain, M. M., Moushumy, M. A., Hoque, M. A., \& Uddin, M. H. (2018). Physico-chemical characterization and microbial studies of the muscle lipid of Indian mackerel (Rastrelliger kanagurta) of the Bay of Bengal. International Journal of Fisheries and Aquatic Studies, 6(6), 268-272.

Bahurmiz, O. M., \& Ng, W. K. (2007). Effects of dietary palm oil source on growth, tissue fatty acid composition and nutrient digestibility of red hybrid tilapia, Oreochromis sp., raised from stocking to marketable size. Aquaculture, 262(2-4), 382-392. http://dx.doi.org/10.1016/j. aquaculture.2006.11.023.

Bahurmiz, O. M., Adzitey, F., \& Ng, W. K. (2017). Nutrient and fatty acid composition of the flesh of oil sardine (Sardinella longiceps) and Indian mackerel (Rastrelliger kanagurta) from Hadhramout coast of the Arabian Sea, Yemen. International Food Research Journal, 24, 2387-2393.

Bandarra, N. M., Batista, I., Nunes, M. L., \& Empis, J. M. (2001). Seasonal variation in the chemical composition of horse-mackerel (Trachurus trachurus). European Food Research and Technology, 212(5), 535-539. http://dx.doi.org/10.1007/s002170100299.

Calixto, F. A. A., Dias, G. E. A., Guimarães, J. L. B., MacHado, E. S., Latini, J. T. P., \& Mesquita, E. F. M. (2020). Analysis of the chemical properties of salted cobia (Rachycentron canadum). Food Science and Technology, 40(Suppl. 2), 722-727. http://dx.doi.org/10.1590/fst.32319.

Celik, M. (2008). Seasonal changes in the proximate chemical composition and fatty acids of chub mackerel (Scomber japonicus) and horse mackerel (Trachurus trachurus) from the northeastern Mediterranean Sea. International Journal of Food Science \& Technology, 43(5), 933 938. http://dx.doi.org/10.1111/j.1365-2621.2007.01549.x.

Chaijan, M., Benjakul, S., Visessanguan, W., \& Faustman, C. (2004). Characteristics and gel properties of muscles from sardine (Sardinella gibbosa) and mackerel (Rastrelliger kanagurta) caught in Thailand. Food Research International, 37(10), 1021-1030. http://dx.doi. org/10.1016/j.foodres.2004.06.012.

Christie, W., \& Han, X. (2012). Lipid analysis: isolation, separation, identification, and structural analysis of lipids. Philadelphia: Oily Press.

Clucas, I. (1982). Present fish drying techniques in Zambia and suggested improvements: report of Fisheries Development Project (FAO Report, No. FI/ZAB/73/009/3). Rome: FAO.

Corapci, B., \& Guneri, N. (2020). Comparative assessment of nutritional composition and physicochemical properties of fresh, freeze- dried and rehydrated rainbow trout (Oncorhynchus mykiss Walbaum, 1792) mince. Food Science and Technology, 40(Suppl. 1), 163-169. http://dx.doi.org/10.1590/fst.08419.

Costa, J. N., Brito, S. A., Leal, A. R., Rodrigues, D. C., Nascimento, L. G. L., Figueiredo, R. W., Mata, P., \& Sousa, P. H. M. (2020). Sensory characteristics of structured guava (Psidium guajava): comparison of optimized descriptive profile, cata and sensory acceptance methods. Food Science and Technology, 40(Suppl. 2), 496-502. http://dx.doi. org/10.1590/fst.25819.

Ganga, U., Radhakrishnan, C., \& Anandan, R. (2010). Fatty acid signatures of the Indian mackerel Rastrelliger kanagurta (Cuvier) 
from the Arabian Sea along the Indian coast. Journal of the Marine Biological Association of India, 52, 8-13.

Gokoglu, N., \& Yerlikaya, P. (2015) Chemical composition of fish. In N. Gokoglu \& P. Yerlikaya (Eds.), Seafood chilling, refrigeration and freezing: science and technology (pp. 5-37). West Sussex: John Wiley \& Sons. http://dx.doi.org/10.1002/9781118512210.ch2.

Håstein, T., Hjeltnes, B., Lillehaug, A., Skare, J., Berntssen, M., \& Lundebye, A. K. (2006). Peligros para la inocuidad de los alimentos que surgen durante la fase de producción: problemas de la piscicultura y la industria piscícola. Revue Scientifique et Technique, 25(2), 607-625. http://dx.doi.org/10.20506/rst.25.2.1678. PMid:17094701.

Hong, H., Fan, H., Wang, H., Lu, H., Luo, Y., \& Shen, H. (2015). Seasonal variations of fatty acid profile in different tissues of farmed bighead carp (Aristichthys nobilis). Journal of Food Science and Technology, 52(2), 903-911.http://dx.doi.org/10.1007/s13197-013-1129-1. PMid:25694699.

Johnston, W., Nicholson, F. J., Roger, A., \& Stroud, G. D. (1994). Freezing and refrigerated storage in fisheries (FAO Fisheries Technical Paper, No. 340). Rome: FAO.

Kumar, M., Annathai, A., Shakila, R., \& Shanmugam, S. (2014). Proximate and major mineral composition of 23 medium sized marine fin fishes landed in the Thoothukudi coast of India. Journal of Nutrition \& Food Sciences, 4(01), 1-7. http://dx.doi.org/10.4172/2155-9600.1000259.

Luzia, L. A., Sampaio, G. R., Castellucci, C. M. N., \& Torres, E. A. F. S. (2003). The influence of season on the lipid profiles of five commercially important species of Brazilian fish. Food Chemistry, 83(1), 93-97. http://dx.doi.org/10.1016/S0308-8146(03)00054-2.

Marichamy, G., Raja, P., Veerasingam, S., Rajagopal, S., \& Venkatachalapathy, R. (2009). Fatty acids composition of Indian mackerel Rastrilliger kanagurta under different cooking methods. Current Research Journal of Biological Sciences, 1, 109-112.

Marques, C., Lise, C. C., Lima, V. A., \& Daltoé, M. L. M. (2020). Survival analysis and cut-off point to estimate the shelf life of refrigerated fish burgers. Food Science and Technology, 40(1), 171-177. http:// dx.doi.org/10.1590/fst.36918.

Mathew, T., Ndamitso, M., Otori, A., Shaba, E., Inobeme, A., \& Adamu, A. (2014). Proximate and mineral compositions of seeds of some conventional and non conventional fruits in Niger state, Nigeria. Academic Research International, 5, 113-118.

Nascimento, R. Q., Tavares, P. P. L. G., Meireles, S., Anjos, E. A., Andrade, R. B., MacHado, B. A. S., Souza, A. L. C., \& Mamede, M. E. O. (2020). Study on the sensory acceptance and check all that apply of mixed juices in distinct Brazilian regions. Food Science and Technology, 40(Suppl. 2), 708-717. http://dx.doi.org/10.1590/fst.37619.

Nisa, K., \& Asadullah, K. (2012). Seasonal variation in chemical composition of the Indian mackerel (Rastrelliger kanagurta) from Karachi Coast. Iranian Journal of Fisheries Science, 10, 67-74.

Nurnadia, A. A., Azrina, A., \& Amin, I. (2011). Proximate composition and energetic value of selected marine fish and shellfish from the West Coast of Peninsular Malaysia. International Food Research Journal, 18, 137-148.

O’Neill, B., Le Roux, A., \& Hoffman, L. C. (2015). Comparative study of the nutritional composition of wild versus farmed yellowtail (Seriola lalandi). Aquaculture, 448, 169-175. http://dx.doi.org/10.1016/j. aquaculture.2015.05.034.

Oliveira, C. M., Borges, E. L., Amaral, R. V. A., Cardoso, N. A., \& Sousa, R. G. C. (2020). Difference in nutritional values between wild and farmed tambaqui in the north region of Brazil. Food Science and Technology. In press. http://dx.doi.org/10.1590/fst.17220.

Oliveira, D. L., Grassi, T. L. M., Bassani, J. S., Diniz, J. C. P., Paiva, N. M., \& Ponsano, E. H. G. (2020b). Enrichment of fish burgers with proteins from surimi washing water. Food Science and Technology, 40(4), 822-826. http://dx.doi.org/10.1590/fst.21319.

Osman, H., Suriah, A. R., \& Law, E. C. (2001). Fatty acid composition and cholesterol content of selected marine fish in Malaysian waters. Food Chemistry, 73(1), 55-60. http://dx.doi.org/10.1016/S0308-8146(00)00277-6.

Pérez, J. A., Rodríguez, C., \& Henderson, R. J. (1999). The uptake and esterification of radiolabelled fatty acids by enterocytes isolated from rainbow trout (Oncorhynchus mykiss). Fish Physiology and Biochemistry, 20(2), 125-134. http://dx.doi.org/10.1023/A:1007795516689.

Pigott, G. M., \& Tucker, B. (1990). Seafood: effects of technology on nutrition. New York: Marcel Dekker.

Romotowska, P. E., Gudjónsdóttir, M., Karlsdóttir, M. G., Kristinsson, H. G., \& Arason, S. (2017). Stability of frozen Atlantic mackerel (Scomber scombrus) as affected by temperature abuse during transportation. Lebensmittel-Wissenschaft + Technologie, 83, 275-282. http://dx.doi. org/10.1016/j.lwt.2017.05.024.

Romotowska, P. E., Karlsdóttir, M. G., Gudjónsdóttir, M., Kristinsson, H. G., \& Arason, S. (2016). Seasonal and geographical variation in chemical composition and lipid stability of Atlantic mackerel (Scomber scombrus) caught in Icelandic waters. Journal of Food Composition and Analysis, 49, 9-18. http://dx.doi.org/10.1016/j.jfca.2016.03.005.

Sahena, F., Zaidul, I. S. M., Jinap, S., Saari, N., Jahurul, H. A., Abbas, K. A., \& Norulaini, N. A. (2009). PUFAs in fish: extraction, fractionation, importance in health. Comprehensive Reviews in Food Science and Food Safety, 8(2), 59-74. http://dx.doi.org/10.1111/j.1541-4337.2009.00069.x.

Sidwel, V. (1981). Chemical and nutritional composition of finfishes, whales, crustaceans, mollusks, and their products. Washington: National Oceanic and Atmospheric Administration.

Sofi, F. R., Raju, C. V., Lakshmisha, I. P., \& Singh, R. R. (2016). Antioxidant and antimicrobial properties of grape and papaya seed extracts and their application on the preservation of Indian mackerel (Rastrelliger kanagurta) during ice storage. Journal of Food Science and Technology, 53(1), 104-117. http://dx.doi.org/10.1007/ s13197-015-1983-0. PMid:26787935.

Sonavane, A. E. (2017). Proximate composition and fatty acid profiling of Indian mackerel (Rastrelliger kanagurta) off Ratnagiri, West Coast of India. Int J Pure App Biosci, 5(4), 920-924. http://dx.doi. org/10.18782/2320-7051.5438.

Sone, I., Skåra, T., \& Olsen, S. H. (2019). Factors influencing postmortem quality, safety and storage stability of mackerel species: a review. European Food Research and Technology, 245(4), 775-791. http://dx.doi.org/10.1007/s00217-018-3222-1.

Tzikas, Z., Amvrosiadis, I., Soultos, N., \& Georgakis, S. (2007). Seasonal variation in the chemical composition and microbiological condition of Mediterranean horse mackerel (Trachurus mediterraneus) muscle from the North Aegean Sea (Greece). Food Control, 18(3), 251-257. http://dx.doi.org/10.1016/j.foodcont.2005.10.003.

Viji, P., Binsi, P. K., Visnuvinayagam, S., Bindu, J., Ravishankar, C. N., \& Srinivasa Gopal, T. K. (2015). Efficacy of mint (Mentha arvensis) leaf and citrus (Citrus aurantium) peel extracts as natural preservatives for shelf life extension of chill stored Indian mackerel. Journal of Food Science and Technology, 52(10), 6278-6289. http://dx.doi. org/10.1007/s13197-015-1788-1. PMid:26396373.

Wickramanayake, T. W., Wijesundera, R., \& Liyanage, D. (1989). Some nutritionally important fatty acids in seven varieties of fish eaten in Sri Lanka. Ceylon Journal of Medical Science, 32, 23-32.

Wijekoon, M. P. A., Parrish, C. C., \& Mansour, A. (2014). Effect of dietary substitution of fish oil with flaxseed or sunflower oil on muscle fatty acid composition in juvenile steelhead trout (Oncorhynchus mykiss) reared at varying temperatures. Aquaculture, 433, 74-81. http://dx.doi.org/10.1016/j.aquaculture.2014.05.028. 